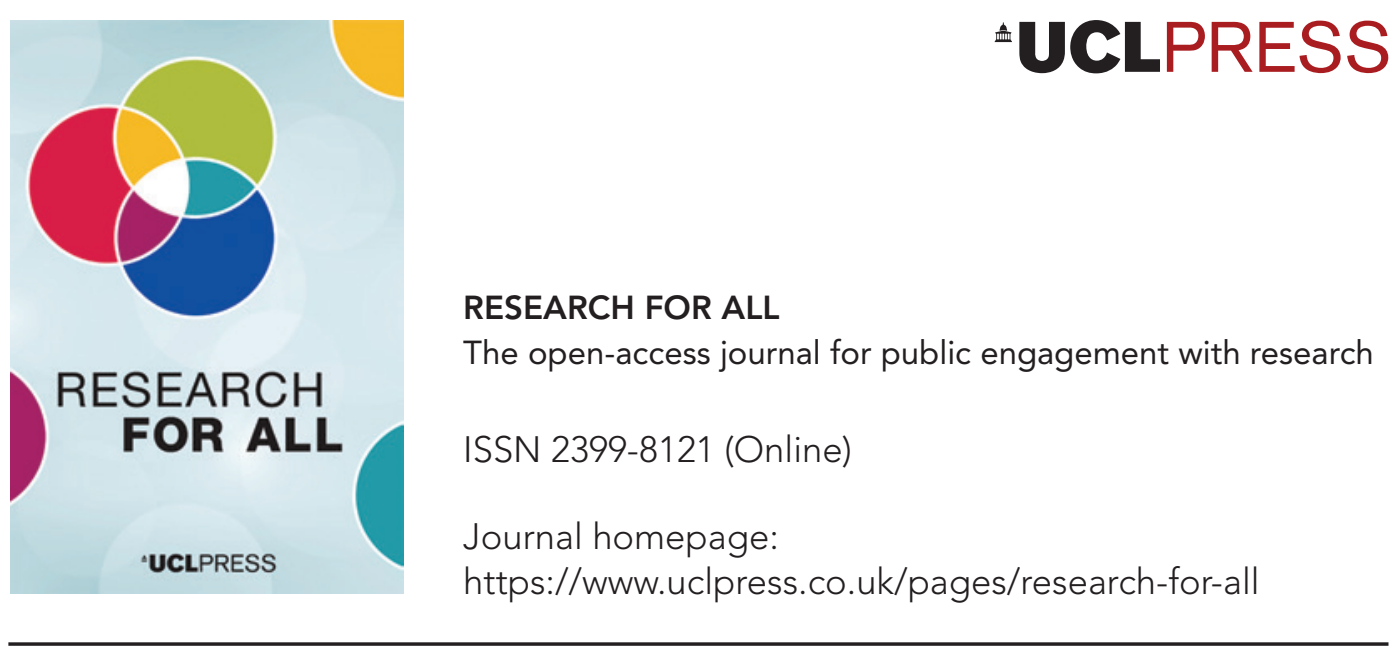

\title{
Creating impact through participatory action research: A film festival framework case study
}

Ruth FarrariD

\section{How to cite this article}

Farrar, R. (2021) 'Creating impact through participatory action research: A film festival framework case study'. Research for All, 5 (1), 118-33. https://doi.org/10.14324/

RFA.05.1.10

Submission date: 1 May 2020

Acceptance date: 29 October 2020

Publication date: 16 February 2021

\section{Peer review}

This article has been peer-reviewed through the journal's standard double-blind peer review, where both the reviewers and authors are anonymized during review.

\section{Copyright}

(C) 2021 Farrar. This is an open-access article distributed under the terms of the Creative Commons Attribution Licence (CC BY) 4.0 https://creativecommons.org/licenses/by/4.0/, which permits unrestricted use, distribution and reproduction in any medium, provided the original author and source are credited.

\section{Open access}

Research for All is a peer-reviewed open-access journal. 


\title{
Creating impact through participatory action research: A film festival framework case study
}

\author{
Ruth Farrar* - Bath Spa University, UK
}

\begin{abstract}
The purpose of this article is to share insights on a novel approach to participatory action research. The significance of my research highlights the benefits of positioning a film festival as a useful participatory action research framework for researchers seeking impact. A film festival approach provides an effective framework for evidencing co-impact throughout the process. The scope of my research focuses on one case study film festival. Shextreme Film Festival is the world's first film festival celebrating women in extreme sports and adventure. In this paper, four guiding steps for reflection and five research insights are outlined for researchers seeking to adopt a film festival within their own discipline as a participatory action research approach to creating impact. An advantage of this approach is that a film festival is an effective creative and public forum for addressing aspirations across industry, community and academic divides. It also empowers a researcher by providing an enterprising approach for commercializing research and sustainably funding long-term projects.
\end{abstract}

Keywords: participatory action research, film festival, women in extreme sports, women in adventure, female adventure film-makers

\section{Key messages}

- Film festivals are useful creative and public forums for addressing aspirations across industry, community and academic divides.

- This film festival approach creates opportunities to fund long-term research projects and commercialize research sustainably.

- Film festivals provide a beneficial participatory action research framework for creating and evidencing co-impact throughout the entire process.

\section{Introduction}

The unique contribution of my research to the field of participatory action research is identifying and investigating a film festival as a framework for researchers seeking impact. This article is based on one case study, Shextreme Film Festival: the world's first film festival celebrating women in extreme sports and adventure. While the themes of this case study are women's film-making, women's well-being and adventure sports, the research insights I learned from this film festival approach can be applied more widely to benefit both arts and humanities academics and science scholars in search of research impact.

The intellectual context and significance of the film festival framework are that it adds new knowledge to participatory action research. It applies terminology from 
this field to the adventure film industry to help an academic engage with industry in an intentional, impactful and meaningful way.

This framework is also significant socially, as this paper argues that film festivals can impact a community of film festival attendees. As I outline in more detail when discussing the collective impact of Shextreme Film Festival, a film festival framework produced research impact and evidently changed behaviour. After watching the Shextreme Film Festival programme, 67.6 per cent of women surveyed over six weeks spent more time outdoors participating in adventure sports, increasing women's mental well-being.

The insights of this paper are also significant economically. The film festival framework introduces a new enterprising solution for academics to sustainably fund long-term impactful participatory action research projects. Research insight 4 in this paper highlights the commercial benefits of this research approach, from film festival fee submissions to advertised film awards.

The insights of this paper matter because impact matters to researchers. This proposed film festival framework provides a researcher with a novel participatory research approach for creating impact.

\section{Why does impact matter to researchers?}

Why has creating research that is measurably impactful beyond academia become increasingly important for a higher education researcher to achieve? It is perhaps partly due to it now becoming a commonplace prerequisite for many academic funding applications. Funders understandably need to be accountable for making clear the greater benefit of funding research projects. This has resulted in impact activities now being woven into research project plans from the outset to secure funding.

Impactful research is also weighted heavily in the UK Research Excellence Framework (REF). Impact case studies will be worth 25 per cent in the REF2021 assessment of academic institutions' research. The REF defines impact as 'an effect on, change or benefit to the economy, society, culture, public policy or services, health, the environment or quality of life, beyond academia', and it is measured in terms of significance and reach (Research England, 2019).

The weighted impact focus of REF2021 combined with Pathway to Impact statements required from research councils has led to 'the impact agenda' (Smith et al., 2020). Concerns have emerged from the impact agenda. For example, the push for social scientists to create policy change to fulfil REF impact case studies metrics 'constrains the ability of social scientists to undertake critical, theoretical and longerterm research' (Smith et al., 2020: 3). Impact is also open to interpretation from different disciplines. Chubb's 2017 PhD thesis on the impact agenda in the UK and Australia revealed life and earth sciences scholars' focus on policy impacts. In contrast, arts and humanities scholars view impact differently, as culturally enriching activities for 'public good' (Chubb, 2017).

All disciplines are united in facing a shared challenge of evidencing impact to meet this impact agenda. As researchers seek impact beyond academia, a positive from this is the rise of collaborative research, and the Higher Education Funding Council for England (HEFCE) notes that collaborative research is one of the fastest sources of research income in UK universities (HEFCE, 2016: 8).

Public engagement involves the many ways in which higher education may share research and engage with the public in 'a two way process ... with the goal of generating mutual benefit' (NCCPE, 2019: n.p.). Designing and delivering a collaborative project 
between academia and the public, in which all parties benefit, poses its own set of challenges. Participatory action research provides helpful approaches for scholars seeking co-created research and impact beyond academia.

\section{What is participatory action research?}

Rather than seeing impact as an end result of a project, participatory action research (PAR) advocates for the need to achieve 'co-impact' instead. For Banks et al. (2017: 542), impact is 'a linear process, based on a donor-recipient model'. In contrast, coimpact champions 'micro process-based impacts that include changes in the thinking and practices of co-researchers' (Banks et al., 2017: 556).

In PAR, participants collaborate with academic researchers as co-researchers involved in some or all of the research design, data collection and dissemination, sharing the same end goal of creating positive social change. Participants' knowledge and experiences are valued. PAR is about change. It often involves empowering marginalized members of society to become heard (Kong et al., 2020).

\section{Participatory action research and film}

One PAR approach for the unheard to become heard is through inclusive co-produced participatory film-making (Dowmunt et al., 2007). InsightShare, a UK non-profit organization, employed a participatory film-making method to activate change and find local solutions. In their documentary defining this method, InsightShare explain that participatory video-making is more than just making a film. Rather, it is a way of 'getting people to unite and plan together to make change in their communities' (InsightShare, 2010). This empowering method enables 'a group or community to see improvements and also to communicate their needs and ideas to decision-makers and/or other groups and communities' (InsightShare, 2020).

Implementing a participatory film-making method can create meaningful impact for the crew of a film. For example, as a film-maker and researcher, I participated in a documentary about how fertility and infertility are portrayed in the media (Levy and Farrar, 2019). Changed behaviour and increased understanding were assessed via qualitative video diaries captured throughout the production. Both film-making crew and participants in the documentary recognized an increase in understanding of the limiting ways that the media portrays this complex topic, alongside learning important biological facts and real-life experiences of fertility and infertility, which widened our initial thinking on this research topic.

Adopting a participatory approach can also create impact for the audience of a film. According to Lambert and the Center for Digital Storytelling, there are seven steps of digital storytelling, beginning with 'owning your insights and emotions', and continuing to the final stage of 'sharing your story' (Lambert et al., 2010: 9, 22). This aspect of 'sharing your story' on film with an audience possesses rich impactful potential. In a large-scale multi-site study in Canada, marginalized people affected by mental illness co-created educational videos about shared issues. Results gained from sharing their 26 films with 1,542 audience members indicate that 'participatory video is a feasible method ... and gives preliminary evidence that resultant videos can reduce viewer stigma' about mental illness (Whitley et al., 2020: 1).

Participation is also created at film screenings by employing methods such as a Q\&A session or panel discussion at the end of a film. Just as a film crew come together to make a film, an audience come together to watch a film collectively. This 
shared experience becomes a starting point for deeper critical dialogue and raised awareness. For example, Cardiff Science on Screen (Cardiff SciSCREEN) hosted film screenings. It used the popular content of the film to attract an audience to connect with a selection of talks by local speakers on a particular science research topic raised by the film, making clear the distinction between a research topic and film content and encouraging audience participation.

Many examples of public engagement and film, and equally the screenings of participatory films, are advertised as one-off film events or a limited screening series. As a researcher, I am interested in exploring a different approach. I propose that the film festival offers a PAR framework for impactful research. This approach is still in its infancy, with limited examples. For context, UK-based Rare Film Festival hosted their first film festival edition dedicated to raising awareness of rare diseases in February 2020.

Instead of exploring the well-documented participant impact of making films, or the viewer impact from participating in one film screening or a single film series, I explore how a novel film festival framework may create and evidence impact.

An argument against using film as an impactful participatory method is that films can be considered monologic. However, this line of inquiry points to the importance of film festivals as an effective framework to deliver films. The structure of a film festival supplementing film screenings with panel discussions and director Q\&A sessions increases the potential for participation.

\section{How can a PAR approach be applied to a film festival framework to create impact?}

The following case study, Shextreme Film Festival, will be analysed to investigate the advantages and challenges of using this film festival framework as a PAR approach to creating impact.

Four guiding steps will be outlined as reflection and insights in chronological order to help researchers understand how to apply these general steps to their specific academic discipline. Five research insights gained from the experience of producing Shextreme Film Festival will also be shared in this case study.

\section{Step 1: Becoming a co-researcher - listening to fellow co-researchers to identify a community need or challenge facing unheard, marginalized people in society}

In 2014, the Shextreme project was formed as a result of listening to women in my local climbing centre and surf club. They communicated their collective frustration at a lack of women being equally represented on screen at adventure film festivals and adventure film tours. For context, in 2010, Banff Mountain Film + Book Festival, dubbed 'the outdoor Oscars', featured only one woman in their film festival's touring programme of 30 adventure films. It was also difficult to search for inspiring, empowering and authentic films and media representations of female athletes and adventurers online. This was evident in surf brand Billabong's divisive 2017 campaign, which featured an active man surfing a big wave versus a passive woman lying on the sand without a surfboard (Willis, 2017).

From these limiting and marginalized female representations, the Shextreme project was born as a curated collection of empowering women in extreme sports and adventure films on a www.shextreme.tv website. This gathering of active women online resulted in feedback and a shared collective desire to meet in person together, which 
resulted in the first Shextreme Film Festival at the Cube Cinema in Bristol in 2015. From its inception, the Shextreme project has been led by audience feedback in order to co-research and co-create the direction of the project. At the time, despite senior marketing managers and brand managers in the outdoor industries warning me against following the women's market, as it was allegedly too small to exist meaningfully, the first edition of Shextreme Film Festival sold out in advance to an audience of early adopters of a hundred athletes, film enthusiasts, adventure journalists and film-makers, thus demonstrating a market and a community need for such a film festival in 2015. Now in its fifth year, Shextreme Film Festival continues to sell out in advance, with its expanded programme, nationwide film tours, and UK and France pop-up screenings having now reached over three thousand audience members.

Research insight 1: Using a film festival framework creates a space in which co-researcher participant feedback is valued, and builds trust and more authentic long-lasting connections in a community.

Rather than imposing my lead researcher agenda or perceived problem on a community, I followed PAR approaches by becoming a co-researcher working collaboratively with fellow co-researchers from the start of a project. After listening to feedback generated from the original Shextreme website, a shared social problem was identified (marginalized women in extreme sports and adventure films). Agreed collective action was then taken, moving from an online website discussion to an inperson film festival, to improve the representation of active women in extreme sports and adventure films and activate and amplify change, helping the unheard become more heard and more visible on the big screen.

This shared social goal from the outset resulted in co-researchers maintaining participant involvement for the full duration of this long-term project, as evidenced by 56 per cent of committed Shextreme Film Festival audience members attending all five Shextreme Film Festival editions to date. The repeated structure of an annual film festival helpfully creates a method to build long-term relationships in the community for an academic researcher in a way that organizing one-off film screening events cannot. Following PAR approaches, returning attendees actively participated in panel discussions, and film-makers shared their evolving cinematic female representations on-screen to collectively co-construct knowledge and the promotion of critical and self-awareness (Mclntrye, 2008).

\section{Step 2: Utilizing a film festival framework to create a 'public sphere' collective of co-researchers from academia, industry and community}

The term 'public sphere' is repeatedly used by Kemmis et al. (2013) in their significant book The Action Researcher Planner: Doing critical participatory action research. Zuber-Skerritt (2016: 152) notes that creating 'a public sphere' means that 'participants contribute differently according to their abilities, strengths and unique gifts/talents, and are free to express their views'. Public spheres can be defined as 'dialogue spaces of optimal learning in the 21st century' (Harris and Wasilewski, 2004), and as 'communal spaces' (Zuber-Skerritt, 2016: 152).

A film festival framework provides an ideal public sphere for an academic to work collaboratively with co-researchers in community and industry to learn, share and communicate insights collectively. Through the cycles of different film festivals, co-researchers' collective long-term knowledge is deepened more meaningfully from diverse perspectives. It is open to changed revision of multiple updates in a way that participation in a one-off film screening does not permit. 


\section{Step 3: Designing processes - when and how to evidence co-impact within a film festival framework}

As previously discussed, PAR approaches focus on 'micro process-based' co-impact throughout the process, rather than viewing impact as an end result of a linear process (Banks et al., 2017). Banks et al. (2017: 542) also define co-impact as 'an umbrella term referring to the generation of change as a result of individuals, groups and organisations working together'.

A film festival requires multiple co-researchers working together in the frenetic creative environment of a film festival to document and evaluate co-impact. As so many interactions take place even in one event within a film festival programme, a challenge for co-researchers is understanding where and how to evidence potential co-impact.

From my experience through the Shextreme Film Festival case study, the following five key areas proved beneficial for evidencing co-impact.

\section{Panel discussions with an audience Q\&A in the cinema}

The method employed here to gather data is a participatory documentary film capturing the panel discussion facilitated by a film-maker member of the Shextreme Film Festival community. A textual analysis of the documentary is then co-created and evaluated between the film-maker and an academic co-researcher to ascertain sound bites of changed perception from the panel speakers and audience during the film festival.

\section{Directly after watching the films, before attendees leave the cinema}

In advance of the film festival, co-researchers from the film festival volunteer team routinely design a one-page quantitative evaluation and qualitative comments paper form to capture changed perceptions and increased awareness. Film festival volunteers work together to hand out and collect back in these evaluation forms at the end of each film festival screening, while new insights are still fresh in attendees' minds. Postfilm festival, co-researchers evaluate the individual written responses. This has proven to be a very effective way of understanding the impact of attendees watching the film festival programme.

\section{Informal discussions in the cinema foyer}

Discovering the unexpected richness of dialogue in the foyer at the first Shextreme Film Festival, mechanisms were then designed for subsequent film festival iterations to capture these valued micro-moments of co-impact.

A participatory documentary film is commissioned in advance of the film festival. Co-researchers agree on a set of five questions to ask attendees, focused on evidencing co-impact and a request for general feedback. Members of the Shextreme Film Festival community are tasked with making these films, including film-maker Jessica Pearson (2016), Director of Shimnix Films and independent film-maker Nic Kane (2019). In written evaluations when each film is complete, every film-maker involved in the collaborative process has described it as 'empowering'. Ensuring that the process is empowering for each film-maker connects with PAR approaches (Kong et al., 2020).

At the film festival, the film-maker works collaboratively with a pair of film festival volunteers to invite dialogue between attendees in the foyer. In audiovisual sound bites, the film-maker captures attendees' changed attitudes to a particular topic as a result of watching the film festival's film programme. A textual analysis of the documentary is 
then co-created and evaluated with the film-maker and an academic co-researcher to evaluate audiovisual sound bites of changed perception among attendees.

This interaction in the foyer, captured both on camera and off camera, is especially helpful for gathering data from attendees who may feel too shy to speak during a panel Q\&A in the cinema. Practising PAR approaches that every experience is valued, this mechanism helps gather different perspectives beyond the main cinema space at a film festival.

\section{An analysis of social media content published about the festival}

Co-researchers and film festival volunteers are designated to create social media content live at the film festival to encourage audience discussion and share reflections. Instagram stories are then saved to analyse post-film festival, helping co-researchers evaluate what aspects of the film festival created the most impact from attendees' perspectives and why.

\section{A post-film festival focus group}

The focus group for each film festival typically comprises six members intentionally selected from different industry, academic and community perspectives. A coresearcher collaborates with each focus group member as a fellow co-researcher in a telephone conversation to ascertain the impact, if any, of attending Shextreme Film Festival. For instance, one focus group included a journalist attendee, a femaleled adventure brand manager from industry who hosted a pop-up shop at the film festival, a featured film-maker, and a committed attendee sharing their reflections as co-researchers. Such focus groups are especially helpful for documenting the longerterm impact of changed behaviours and practices beyond the immediate communal space of attending Shextreme Film Festival. For example, a film programmer directly changed the way they curated the programme of their own large adventure film festival by including more cinematic representations of diversity and inclusion as a direct result of attending Shextreme Film Festival. The festival provided a welcoming space for the programmer to meet new people outside their network, and access to watching new films helping marginalized voices be heard in adventure films. This useful data would have been missed without implementing the post-film festival focus group.

Research insight 2: When evidencing co-impact, the super-niche themed focus of a film festival creates increased awareness.

A major advantage of proposing a film festival as a PAR approach is the necessary thematic focus of a film festival. During a podcast recording, Mark Cosgrove, Head Cinema Curator at Watershed Cinema in Bristol, commented on the rise of film festivals containing a super-niche, which adds to the successful audience development of film festivals such as Shextreme Film Festival (Cosgrove and Berry, 2019). Film festivals facilitate this specialist focus, which complements the specialized focus of research projects. As a result of the super-niche focus - women in extreme sports and adventure - each festival's data revealed 99 per cent of audience members believed that attending Shextreme Film Festival resulted in increased awareness and understanding of women in extreme sports and adventure:

It's woken me up. I now get it: extreme sports and the outdoors are a privilege. I learned something new about improving access and support for female surfers in Jamaica, who face so many cultural challenges before even getting in the water. 
It has opened my eyes to a new way of living, especially in later life. I now understand adventures are possible, no matter how small or large, for women of all ages!

It's made me realize we need more of this. So inspiring watching women in adventure's achievements. Only wish Shextreme Film Festival was around when I was growing up. These films act as great role models for women as we become what we can see.

I got brought along to this as a plus one and was kind of blown away. It felt inclusive for men and women to attend. I now feel fired up to help my female friends succeed in mountain biking.

So cool. Loved the world premiere of Boarders Without Borders (2018). Had no idea UK's first longboarding women of colour crew had formed here in Birmingham. Inspired to continue their mission now in other cities as they've shown me what is possible.

An unexpected outcome of this increased awareness of women in extreme sports and adventure as a result of attending Shextreme Film Festival has led to further amplification of increased awareness and understanding and, most importantly, decisive action. The film festival provided a useful meeting platform for like-minded women, which has led to the birth of numerous film projects. Women attending the festival have gone on to make their own films to submit to future Shextreme Film Festival editions. For example, athlete and journalist Monet Adams, who attended and wrote about the festival from its inception (Adams, 2015), went on to world premiere her mountain biking film Just Be, filmed in Norway, at 2019's Shextreme Film Festival.

Figure 1: Audiovisually recorded audience feedback and event highlights from Shextreme Film Festival 2016, documenting the audience's increased awareness and deeper understanding of women in extreme sports and adventure as a result of attending the film festival. Still from Shextreme Film Festival's highlights film (2016), showing adventure film Circle of the Sun produced by and starring Lena Stoffel surfing and skiing in Norway. Photography Credit: Inigo Grasset. Video at: www.youtube.com/watch?v=RMH_JUFyfw0\&feature=youtu.be

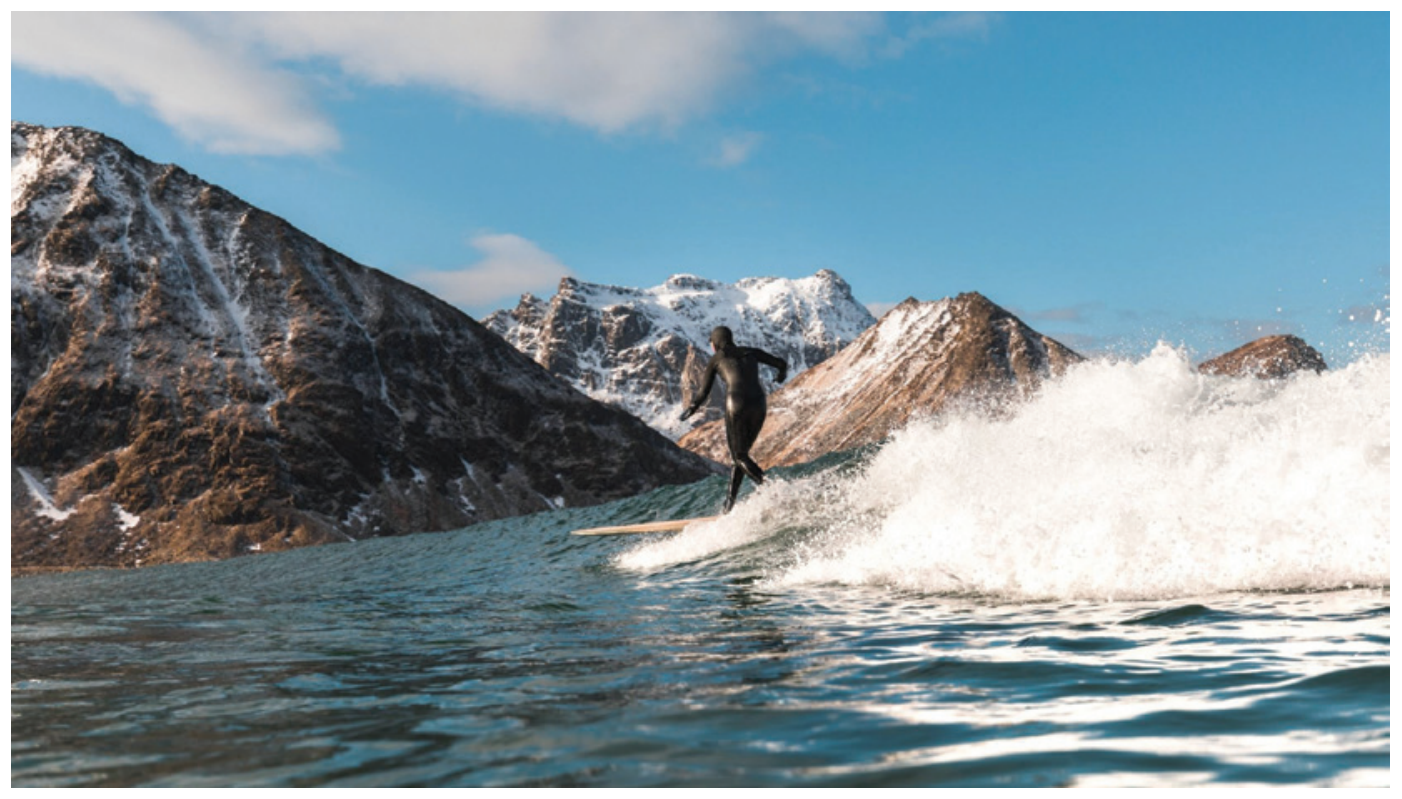


Another case study is environmentalist, vet and adventurer Cal Major, who attended our film festival's film screenings and our one-day Shextreme Film School event as part of the film festival's expanded programme. Shextreme Film School was introduced in the second year of the festival after evaluating a community need for guidance on getting started in adventure film-making. Shextreme Film School is co-led at every film festival by film-makers featured in the film festival programme, sharing professional tips to emerging talent.

Through participating in the film festival's Shextreme Film School programme, Cal felt inspired to collaborate with two of the film festival's panel speakers, Bex Band and Mollie Hughes, to improve the representation of women in adventure films. This led to the collective action of a funded adventure and a commissioned short film about their desert expedition, challenging how women in adventure are perceived in Jordan (Major, 2017). Cal also commented on how she felt 'more confident and empowered' to make her first solo stand-up paddleboarding (SUP) adventure film Skye's The Limit (2017) after attending Shextreme Film Festival's first Shextreme Film School in 2016. Her female-led adventure film has gone on to win numerous awards, such as the John Muir Trust Wild Places Award in 2017.

\section{Step 4: Using the film festival framework as an introductory meeting point to create industry and community solutions beyond the festival}

The success of Cal Major's film led me to understand the role that film festivals may play not only in screening content, but also in nurturing talent: 100 per cent of Shextreme Film School attendees noted that attending Shextreme Film School had boosted their confidence and understanding of adventure film-making. However, feedback also revealed that attendees would like more support. Herein lies perhaps a disadvantage of a film festival as a PAR approach.

Research insight 3: A disadvantage of a film festival approach is its limited time frame in person to activate impact. However, feedback and knowledge gained from the film festival can be used to activate change in industry and communities post-film festival.

A film festival provides a concentrated short time frame of connection and support, often lasting from one to three days. For Peter Harald Maskell et al. (2006), film festivals function as 'knowledge pipelines' because they connect local crews with global collaborative networks. However, such opportunities to gain connections are realistically short-lived. Film festivals' programming of masterclasses or film schools encourages talent development. However, film festivals as helpful 'ecologies of learning' (Levitt and March, 1988: 320; Rüling, 2009) only act as temporary solutions, because this level of inperson support often disappears until the next film festival a year later.

Shextreme Film Festival attendees commented on the need for more support and advice throughout the year, as a film can take months if not years to make. At the same time, through running the film festival, professional relationships in industry have been formed, including with sponsors, professional athletes and journalists. In focus group discussions, which I carry out post-film festival (this method is discussed in more detail earlier in this paper), film curators, film-makers and brand managers collectively, although privately, all pointed out the perceived lack of highly trained female adventure film-makers and photographers. In public, Banff Mountain Film + Book Festival responded to the 2010 criticisms (mentioned above) in an open forum on their website, fairly pointing out the lack of high-quality content featuring female adventurers and extreme sports athletes submitted to their festival as one of the 
Figure 2: Audiovisually captured participant feedback about our adventure photography workshop training more women behind the camera. Still from Shextreme Adventure Photography Workshop participant's feedback film (2019), showing four participants behind the scenes on location during an adventure photography shoot in Chamonix, France. Photography Credit: Ruth Farrar. Video at: www.youtube.com/watch?v=D7iPYewRepl\&feature=youtu.be

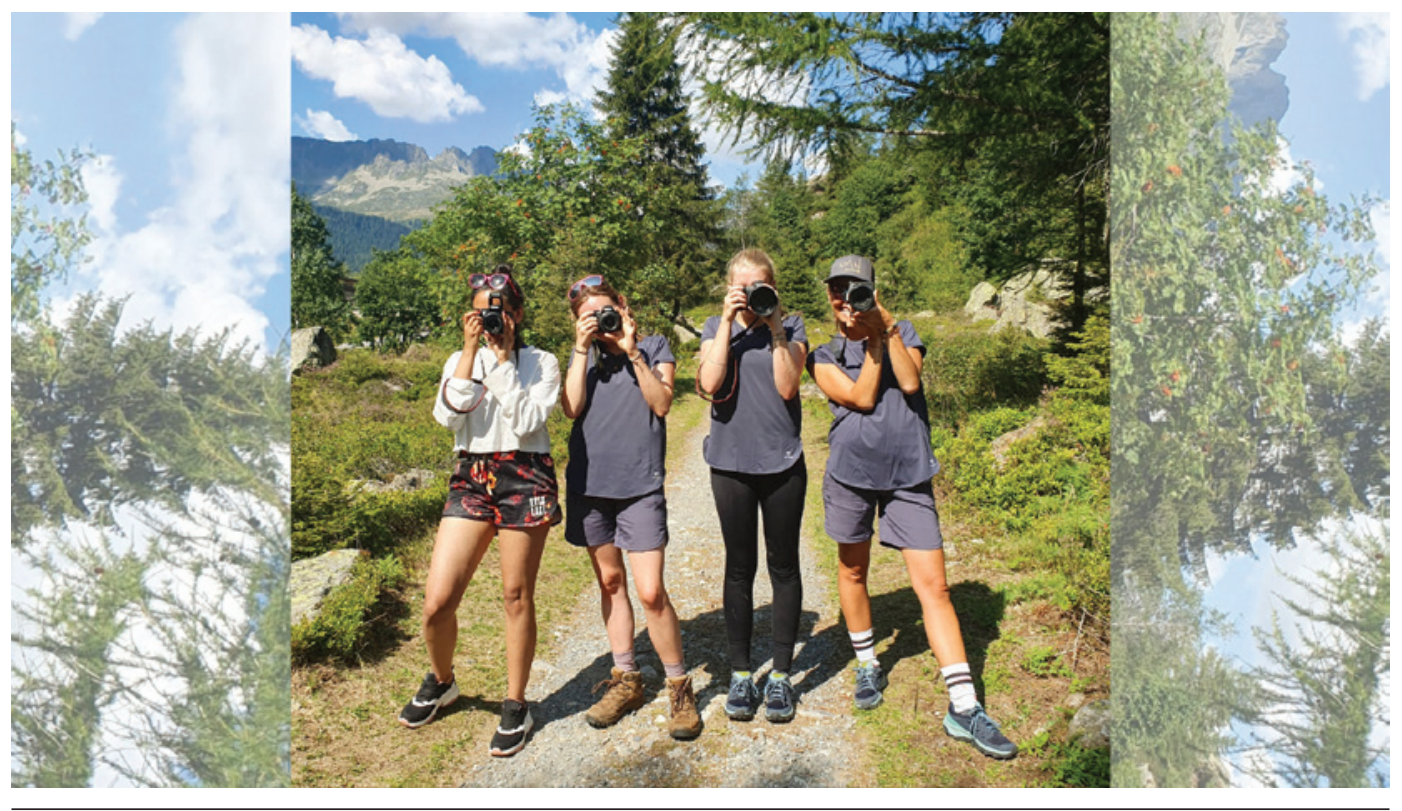

key reasons that women were less represented as part of their film festival's touring programme.

Participating as a co-researcher, and as Festival Director, I listened to the needs of the audience of Shextreme Film Festival for more support, and to Shextreme Film Festival industry partners' aspirations to work with more female talent behind the camera. Understanding this industry problem of wanting more female-led films with high production values to be made, I acknowledged the limitations of a film festival approach in meeting these industry and audience aspirations. Instead, I channelled this feedback into founding Shextreme Alliance, which was introduced at Shextreme Film Festival 2018. Shextreme Alliance is the world's first international network celebrating, supporting and training female adventure film-makers, photographers and media makers. Support comes in the form of monthly Ask the Expert Masterclasses sharing best practices and in-person workshops throughout the year, including a mountain bike photography workshop in the Forest of Dean, UK, and an adventure photography workshop co-led with adventure brand Salomon, female adventure company Boundless Betty, and Canon camera ambassador Krystle Wright in Chamonix, France in 2019.

Shextreme Alliance also disrupts the typical model of gaining adventure film-making and photography work, increasing the representation of women behind the camera by providing direct access for 'outsider' women to learn about 'insider' opportunities in the outdoor adventure industries. International jobs shared with Shextreme Alliance members have ranged from photography work in Sri Lanka for adventure organization She Flies to filming a female-led wilderness canoe expedition in Quebec, Canada.

\section{What co-impact resulted from Shextreme Film Festival?}

To categorize the amassed multilayered evidenced moments of co-impact throughout the five-year film festival process to date, Banks et al.'s (2017) conceptual framework for 
PAR co-impact is useful. It is based on a three-fold distinction between 'participatory', 'collaborative' and 'collective' impact as summarized below:

1) Participant impact (process based). Banks et al. (2017: 543) define this processbased category of impact as 'changes in the thinking, emotions and practice' that occur as a result of co-researchers' involvement in conducting PAR.

2) Collaborative impact (findings based). Banks et al. (2017: 550) define this as 'the effects of the findings of research that has been conducted collaboratively on both internal and external people and organisations'.

3) Collective impact. Banks et al. (2017: 543) define this as 'a deliberate strategy on the part of the research partners (and sometimes others) to achieve a specific, targeted change in practice and/or policy based on issues highlighted'.

In terms of the first point, participant impact, participating in Shextreme Film Festival essentially changed my behaviour as a researcher when seeking funding. It does not fit in with a clear time frame as it is an ongoing PAR project. Therefore, alternative funding was secured from the beginning to create a sustainable self-funded model. Shextreme Film Festival successfully self-funds its next iteration, securing funding from several revenue streams. This method includes: a film festival submission fee charged via an industry film festival submission platform, FilmFreeway; attendee ticket sales; industry partners sponsoring the festival through film awards; advertisement space in the printed festival programme; and paying for a pitch as a mutually beneficial popup shop connecting female-led adventure brands with audiences of active women at Shextreme Film Festival. This enterprising method of research funding is an advantage of this film festival approach because it empowers a researcher knowing that they can securely continue to run a long-term research project which is not reliant on the outcome of highly competitive academic research grants, which can be timeconsuming to apply for and then await feedback.

Research insight 4: Adopting a film festival framework creates new enterprising options to commercialize research activities and fund longterm research projects.

A benefit of applying a film festival approach to funding long-term PAR research projects is the enterprising opportunity for increased funding through expansion. If your film festival is successful at a grass-roots level, negotiating the next steps for expansion to meet audience aspirations is complex, but possible. For example, I was successful in two funding bids to expand Shextreme Film Festival's programme to tour its film festival programme in 2017 and 2019 in the UK's South West. Funding from the British Film Institute's Film Audience Network facilitated this expansion. Gaining financial support for the first two South West-based tours afforded me time to build relationships and build up funds to then promote a national Shextreme Film Festival programme touring in over twenty cinemas in Wales, England, Scotland and Northern Ireland in 2019 and 2020. This demonstrates the innovative ways available to continue expanding funding opportunities, if pursuing this unique enterprising method to secure research funding via a film festival approach.

Examining the second point above, the collaborative impact of Shextreme Film Festival, an illustrative example includes the findings from a research survey on the impact of film in helping encourage women to spend more time outdoors. The following survey is an example of how researchers can leverage a film festival framework in order to carry out valid academic research with long-term follow-up.

In response to previous audience feedback on mental well-being, a co-created research survey was launched at Shextreme Film Festival 2017. The survey was a 
collaboration between the Shextreme community and the survey's lead researcher, Hetty Key, founder of the Women in Adventure organization in industry.

We connected with survey partners to ensure that the survey's design and data were meaningful and beneficial for organizations helping support women in adventure. Survey partners included climbing and mountaineering brand Rab, the Outdoor Women's Alliance in the USA and the Outdoor Industries Association in the UK.

It was a surprisingly very smooth and fast process signing up influential industry partners from the outdoor industries to the survey. This points to an advantage of a film festival PAR framework. Some had already participated as a Shextreme Film Festival panel speaker or audience member, or were already internationally aware of the festival through social media and industry professional word-of-mouth recommendations. They trusted and clearly understood the ethos of the Shextreme and Women in Adventure research survey in a tangible, meaningful and practical way; perhaps sharing a higher education article or book as the pitch would not have had the same effective hook for non-academic professionals to confirm as public industry partners quickly.

We utilized the platform of Shextreme Film Festival to launch the survey in 2017. Here is another benefit of using a film festival framework, as there was already a natural gathering of our target audience for this research survey. Through Shextreme Film Festival's community and our survey's industry partner networks, we reached over 2,500 survey participants worldwide.

Adding to the literature on women in adventure (Cole et al., 1994; Barnard et al., 2018; Williams, 2018), this research survey explored the association between spending time outdoors participating in adventure sports and women's mental well-being. One central finding was discovering that women who kayak have the best mental well-being of the top ten adventure sports surveyed, followed by women who ski (Key and Farrar, 2019). The survey's quantitative data also measurably reflected original qualitative data gathered from Shextreme Film Festival confirming that 99 per cent of women in adventure find that the outdoors has a positive impact on mental well-being (Key and Farrar, 2019).

The survey also revealed that 67.6 per cent of women agreed that female-led adventure films encouraged and inspired them to spend more time outdoors (Key and Farrar, 2019). I was keen to explore this particular film data finding further using the film festival's PAR approach to seeking impact. How do you assess changed behaviour over time as a result of attending the programme of Shextreme Film Festival?

Some methods exist for recognizing changed behaviour immediately after a film screening (Langdridge et al., 2019). However, I wanted to ascertain a 'before' and 'after' to assess the impact, if any, beyond the film event. A co-created solution emerged after sharing my research challenge with fellow participants at the National Co-ordinating Centre for Public Engagement's Engage Academy, an instrumental year-long training programme that I attended from 2018 to 2019 with UK-based academics to learn more about public engagement for researchers.

After consulting with attendees, I refined my method of measuring the longterm impact of attending a film encounter. It involved three assessment phases: before entering the cinema screening, just after the screening, and again six weeks after attending the event.

This data finding was further investigated through Shextreme Film Festival's 2019 touring programme in Exeter: Phoenix, The Poly in Falmouth, and The Lighthouse Cinema in Newquay, reaching 470 audience members.

First, audience members self-selected their level of time spent in the outdoors participating in adventure sports through a sticker chart system before entering the 
cinema, to ascertain a collective base-level understanding of time typically spent outdoors. This simple low-fi method proved very popular. While it was voluntary, at each screening, a queue formed, as the majority of audience members wanted a sticker and enjoyed the interactive element, which sparked great conversations.

After the festival's screening, audience members individually completed a written survey; 100 per cent of surveyed attendees found that watching Shextreme Film Festival's programme inspired them to spend more time outdoors participating in adventure sports. An opt-in focus group of women then completed another online survey six weeks after attending the festival; 67.6 per cent of women in the focus group recognized an increase in time spent outdoors participating in adventure sports after watching Shextreme Film Festival's on tour programme. While only one study, these research data reveal the impact that film festival programming may have, indirectly and measurably changing behaviours.

Results were disseminated through an online report shared with the British Film Institute's Film Audience Network's South West Hub. A short $16 \mathrm{~mm}$ documentary film was made, inspired by the results, entitled Nurture, highlighting the mental well-being benefits of mountain biking from a female perspective (Farrar, 2019), and the results also impacted the way Shextreme Film Festival 2019 was programmed. Using women in adventure's mental well-being as its theme, a new event in the festival was created called Wheels, Waves and Wellbeing, sharing female-led adventure films promoting the benefits of the outdoors on mental well-being alongside a research talk and panel discussion. Audience feedback from the event showed that 100 per cent of attendees were inspired to now spend more time outdoors participating in adventure sports.

Research insight 5: Watching a film festival programme can create impact by assessing participants' changed behaviours.

Figure 3: Impact of Shextreme Documentation capturing the impact of attending Shextreme Film Festival 2019, including sound bites on the women in adventure mental well-being survey results from multiple perspectives, including Dr Ruth Farrar, Hetty Key, audience members, adventurers, athletes, panel speakers and film-makers. Still from Impact of Shextreme Documentation (2019), featuring Monet Adams at Shextreme Mountain Biking Photography Workshop in the Forest of Dean, UK. Photography Credit: Saskia Dugon. Video at: www.youtube.com/ watch?v=V6oSDUH9RPg\&feature $=$ youtu.be

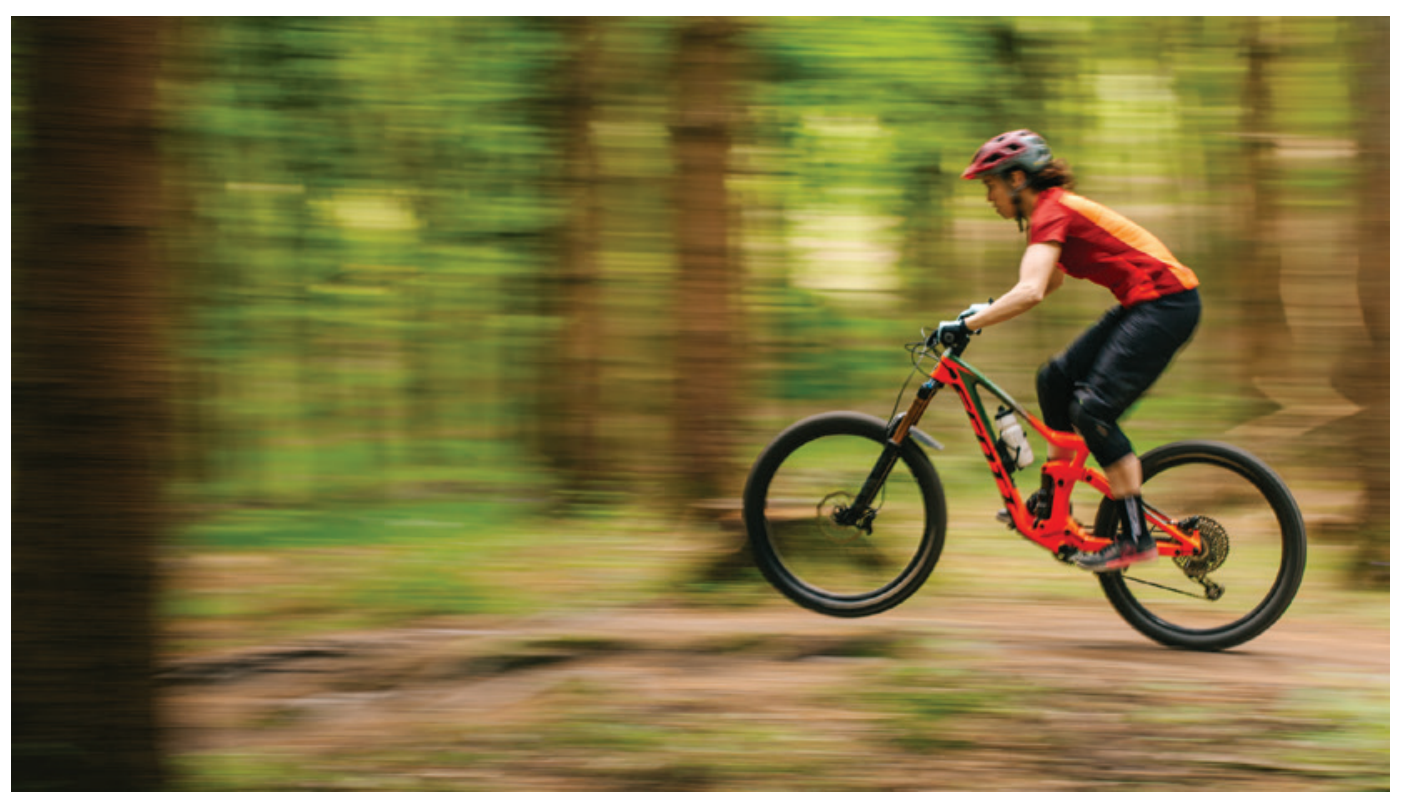


Concerning point 3 of the conceptual framework for co-impact, above - collective impact - this is evident in the formation of the previously discussed Shextreme Alliance. This network is a result of taking action to achieve a community aspiration learned through Shextreme Film Festival attendee feedback. Members of this international network work together to change the way female-identifying adventure film-makers and photographers share knowledge. Mechanisms for sharing professional advice to advance members' practice include monthly online Ask the Expert Masterclasses and in-person adventure photography workshops in the UK and France.

In the male-dominated world of adventure film-making, which is reflective of the wider film industry's gender inequality issues (Directors UK, 2018), setting up the Shextreme Alliance network has also activated social change beyond the film festival. It has positively impacted the hiring practices of adventure brands. Progressive brands seeking to champion gender equity behind the camera, and to diversify their talent pool, now utilize Shextreme Alliance as a helpful resource for advertising paid job opportunities. Brands signed up to Shextreme Alliance's jobs board include Roxy and ACAl Outdoorwear. These paid jobs empower Shextreme Alliance members as they gain industry experience, industry contacts and up-levelled production skills. This helps to increase their industry profile, thus tackling the issue of marginalized female representation in the field of adventure film-making.

\section{Conclusion}

A film festival provides an ideal 'public sphere' and forum for addressing aspirations across industry, community and academic divides. The film festival framework can also be leveraged to carry out valid research, as evident in the research survey on women's mental wellbeing and the outdoors. In the case study in this paper, this film festival approach creates evidenced impact at participant, community and collective levels.

Adopting a film festival framework for a researcher may prove advantageous when seeking research impact, as this approach measurably results in increased awareness and positive changed behaviour. Spanning over five years, reaching 3,000 audience members, the case study Shextreme Film Festival has demonstrated that 99 per cent of attendees reported a deeper understanding and increased awareness of women in extreme sports and adventure.

Attending a film festival may also lead to changed behaviour. Tracked over a six-week period, after watching Shextreme Film Festival's female-led adventure film programme in 2019, women were encouraged and inspired to spend more time outdoors participating in adventure sports. Another positive reason to apply a film festival framework as a PAR method is its potential to fund long-term research projects sustainably.

However, there are challenges to this approach, including the somewhat limiting time frame of a film festival programme to facilitate in-person encounters, often only lasting one to three days per year.

Shextreme Film Festival attendees identified a community aspiration for yearround adventure film-making support. This led to the action of founding Shextreme Alliance, the world's first international network providing year-round support and training for female adventure film-makers and photographers. A film festival provides a helpful framework to evidence impact at industry level too. The film festival's activities and action taken, such as forming Shextreme Alliance, led to a change in who brand managers hire for filming campaigns.

This paper is limited to only one deep analysis case study, so further study is required to apply this film festival framework to different disciplines. However, it does 
highlight a film festival as a novel PAR approach for a researcher seeking to create and evidence impact.

\section{Acknowledgements}

Thank you to all the adventure brands for helping fund Shextreme Film Festival. These include Ellis Brigham, Nike SB, Rab, Peak Jewellery, Finisterre and Roxy. I am grateful for collaborating with hard-working teams in independent cinema spaces, including The Cube Cinema, Arnolfini, Exeter: Phoenix, The Poly, the Lighthouse Cinema and the Watershed Cinema. Financial support from the British Film Institute's Film Audience Network is gratefully appreciated. Thank you for your research expertise and collaboration, Hetty Key. Finally, a special thank you to our Shextreme Film Festival audience, guest speakers, featured film-makers and dedicated volunteers for sharing your insights so generously as valued co-researchers working towards our shared mission of improving gender equity in adventure films on screen and behind the camera.

\section{Notes on the contributor}

Ruth Farrar is a Reader in Creative Media and Enterprise, and Director of Artswork Media production company at Bath Spa University. She is a film-maker, binaural sound artist and Director of Shextreme Film Festival. Ruth has produced media for clients including Carnegie Hall, Vogue and Discovery. Ruth's award-winning films have been screened at the British Film Institute and film festivals from California to Cannes.

\section{References}

Adams, M. (2015) 'Monet at Shextreme - The world's first female extreme sports festival'. Wide Open. Accessed 1 October 2019. www.wideopenmountainbike.com/2015/10/shextreme-theworlds-first-female-extreme-sports-festival.

Adams, M. (2019) Just Be. Accessed 18 October 2019. www.scott-sports.com/gb/en/video/bike/ just-be-with-monet-adams.

Banks, S., Herrington, T. and Carter, K. (2017) 'Pathways to co-impact: Action research and community organising'. Educational Action Research, 25 (4), 541-59. https://doi.org/10.1080/096 50792.2017.1331859.

Barnard, C., Carter, C., Dawe, H., Mort, H. and Harrison, M. (2018) Waymaking: An anthology of women's adventure writing, poetry and art. Sheffield: Vertebrate Publishing.

Chubb, J. (2017) 'Instrumentation and Epistemic Responsibility: Researchers and the impact agenda in the UK and Australia'. PhD thesis, University of York.

Cole, E., Erdman, E. and Rothblum, E.D. (1994) Wilderness Therapy for Women: The power of adventure. New York: Haworth Press.

Cosgrove, M. and Berry. T. (2019) 'Watershed: October 2019 cinema podcast'. Accessed 20 October 2019. www.watershed.co.uk/audio-video/october-2019-cinema-podcast.

Directors UK (2018) Who's Calling the Shots? Gender inequality among screen directors working in UK television. Accessed 21 October 2020. https://d3gujhbyl1boep.cloudfront.net/ uploads\%2F1534498780256-1us01ik1t7s-53673fec300aa64609cd02b8619dca90\%2FDirectors+UK+ Who\%27s+Calling+the+Shots+August+2018+FINAL.pdf.

Dowmunt, T., Dunford, M., Van Hemert, N. and Fountain, A. (2007) Inclusion Through Media. London: Goldsmiths, University Of London.

Farrar, R. (2019) Nurture [Film]. UK: Artswork Media.

Harris, L.D. and Wasilewski, J. (2004) 'Indigeneity, an alternative worldview: Four R's (relationship, responsibility, reciprocity, redistribution) vs two P's (power and profit). Sharing the journey towards conscious evolution'. Systems Research and Behavioral Science, 21 (5), 1-15. https://doi.org/10.1002/sres.631.

HEFCE (Higher Education Funding Council for England) (2016) Higher Education in England 2016: Key facts. Accessed 23 October 2020. https://dera.ioe.ac.uk/27280/1/HEFCE2016_20.pdf. 
InsightShare (2010) Animation: What is participatory video. Accessed 22 October 2020 www.youtube. .com/watch?reload=9\&v=seOstch03j8.

InsightShare (2020) 'Participatory video methods'. Accessed 22 October 2020. https://insightshare. org/methods/.

Kane, N. (2019) Impact of Shextreme [Film]. UK: Shextreme Film Festival.

Kemmis, S., McTaggart, R. and Nixon, R. (2013) The Action Research Planner: Doing critical participatory action research. 4th revised ed. Singapore: Springer Verlag.

Key, H. and Farrar, R. (2019) Women in Adventure: Mental Wellbeing Survey results. Accessed 1 October 2019. https://womeninadventure.com/mental-wellbeing/.

Kong, S.T., Banks, S., Brandon, T., Chappell, S., Charnley, H., Hwang, S.K., Rudd, D., Shaw, S., Slatcher, S. and Ward, N. (2020) 'Extending voice and autonomy through participatory action research: Ethical and practical issues'. Ethics and Social Welfare, 14 (2), 220-9. https://doi.org/10.1080/17496535.2020.1758413

Langdridge, D., Gabb, J. and Lawson, J. (2019) 'Art as a pathway to impact: Understanding the affective experience of public engagement with film'. The Sociological Review, 67 (3), 585-601. https://doi.org/10.1177\%2F0038026118822822.

Lambert, J., Hill, A., Mullen, N., Paull, C., Paulos, E., Soundararajan, T. and Weinshenker, D. (2010) Digital Storytelling Cookbook. Accessed 18 October 2020. https://wrd.as.uky.edu/sites/default/ files/cookbook.pdf.

Levitt, B. and March, J.G. (1988) 'Organizational learning'. Annual Review of Sociology, 14, 319-40. https://doi.org/10.1146/annurev.so.14.080188.001535.

Levy, C. and Farrar, R. (2019) (In)fertility the Media and Me. UK: Bath Spa University.

Major, C. and Appleton, J. (2017) Skye's The Limit. Accessed 6 December 2019. www.calmajor.com/ skyes-the-limit.

Major, C. (2017) 'Hike Jordan'. Accessed 8 December 2019. www.calmajor.com/hike-jordan.

Maskell, P., Bathelt, H. and Malmberg, A. (2006) 'Building global knowledge pipelines: The role of temporary clusters'. European Planning Studies, 14 (8), 997-1013. https://doi.org/10.1080/09654310600852332.

Mclntyre, A. (2008). Participatory Action Research. Los Angeles: Sage.

NCCPE (National Co-ordinating Centre for Public Engagement) (2016) 'What is public engagement?' Accessed 14 December 2019. www.publicengagement.ac.uk/explore-it/whatpublic-engagement.

Pearson, J. (2016) Shextreme Film Festival 2016: Highlights and audience feedback. UK: Shimnix Films.

Research England (2019) 'REF impact'. Accessed 4 October 2019. https://re.ukri.org/research/refimpact/.

Rüling, C.C. (2009) 'Festivals as ecologies of learning'. Paper presented at the third annual conference 'Cultural production in a global context: The worldwide film industries', London, June.

Smith, K., Bandola-Gill, J., Meer, N., Stewart, E. and Watermeyer, R. (2020) The Impact Agenda: Controversies, consequences and challenges. Bristol: Policy Press.

Stringer, P. (2018) Boarders without Borders [film]. UK: GirlDreamer.

Whitley, R., Sitter, K., Adamson, G. and Carmichael, V. (2020) 'Can participatory video reduce mental illness stigma? Results from a Canadian action-research study of feasibility and impact'. BMC Psychiatry, 20 (1), article 16. https://doi.org/10.1186/s12888-020-2429-4.

Williams, S. (2018) 'Adventure, Women and Fear'. MA thesis, University of Lancaseter.

Willis, A. (2017) 'Billabong ran these two surf adverts and people got angry'. Metro, 20 August. Accessed 18 October 2019. https://metro.co.uk/2017/08/20/billabong-ran-these-two-surfadverts-and-people-got-angry-6863285/.

Zuber-Skerritt, O. (2016) 'The action research planner: Doing critical participatory action research'. Educational Action Research, 24 (1), 150-4. https://doi.org/10.1080/09650792.2015.113 2591. 